\title{
ANALISIS EFISIENSI PASAR MODAL BENTUK SETENGAH KUAT
}

\author{
Noviarti", Melkisedek \\ *) Dosen Tetap Program S1 Jurusan Manajemen Fakultas Ekonomi Universitas Satya Negara Indonesia \\ noviarti.arif@gmail.com,melkisedekfransiskus@.gmail.com
}

\begin{abstract}
The Purpose of This study to examine the efficiency of the half-strong form of capital market information with observing whether there are abnormal stock returns around dividend announcements, as well as the reaction speed of the capital market to dividend announcements. The company that has been studied is manufacturing sector companies listed on the Indonesian stock exchange for 4 years from 2014-2017. This type of research is event study. The research population is manufacturing companies listed on the Indonesia Stock Exchange. Samples that have been selected in this study were determined by purposive sampling method that is by several criteria. Of the 144 manufacturing companies totaling 118 not shared dividends as a whole, only 26 companies met the criteria as research samples. Based on the results of the study, it can be concluded that the Indonesian Capital Market is efficient in the form of half strong around the event of dividend announcements and has information content. This is indicated with the existence of a significant abnormal return on the seventh and first day $(t-7 \& t-1)$ before the event date and the fourth and eighth days after the event date $(t+4$ and $t+8)$. at $t-7$ and $t-1$, indicates a leak of information about dividend announcements so that on the day of the announcement the market does not react significantly. On the fourth day $(t+4)$ investors can absorb new information. On the eighth day $(t+8)$ investors try to take advantage of profits, but the market quickly makes a balance so investors cannot use it to take advantage.
\end{abstract}

Keywords : Dividend announcements, Abnormal stock returns, , Information content, Capital market efficiency is a half-strong form.

\section{PENDAHULUAN}

Pengujian efisiensi pasar modal setengah kuat secara informasi dilakukan dengan tujuan melihat ada tidaknya abnormal return saham di seputar pengumuman dividen, serta kecepatan reaksi dari pelaku pasar terhadap pengumuman dividen. Pengujian secara empiris mengenai reaksi pasar terhadap pengumuman dividen menjadi perhatian para peneliti, karena hal tersebut bertentangan dengan dividend irrelevance theory, yang dikemukakan oleh Miller dan Modigliani (1961). Selisih antara actual return dan expected return dapat berupa positif dan negatif, jika positif berarti return yang sesungguhnya lebih besar dari return yang di harapkan oleh investor, dan jika negatif berarti return yang sesungguhnya lebih kecil dari return yang di harapkan oleh investor. Abnormal return yang positif menjadi pemicu untuk para investor melakukan transaksi disekitar pengumuman informasi dengan harapan mendapatkan Profit di atas rata-rata atau biasa di sebut abnormal return.

Konsep pasar efisien menyiratkan adanya suatu proses penyesuaian harga sekuritas sebagai respon atas informasi baru yang masuk ke pasar menuju harga keseimbangan yang baru. Peristiwa pembagian dividen tunai bagi investor sangatlah penting artinya, karena pengumuman dividen tunai dianggap sebagai suatu sinyal positif. Dengan melakukan pembagian dividen, manajer perusahaan ingin menyampaikan bahwa perusahaan masih memiliki prospek di masa yang akan datang.

Pada konsep pasar semi kuat, investor tidak akan mampu untuk memperoleh abnormal return dengan menggunakan strategi yang dibangun berdasarkan informasi yang tersedia di public. Dengan kata lain, analisis terhadap laporan keuangan tidak memberikan manfaat apa-apa. Ide dari pandangan ini adalah bahwa sekali informasi tersebut menjadi informasi public (umum), artinya tersebar di pasar, maka semua investor akan bereaksi dengan cepat dan mendorong harga naik untuk mencerminkan semua informasi public yang ada. Konsep pasar efisien menyiratkan 
adanya suatu proses penyesuaian harga sekuritas menuju harga keseimbangan yang baru, sebagai respon atas informasi baru yang masuk ke pasar.

Penelitian ini perlu dilakukan karena masih ada gap yang ditemui pada beberapa perusahaan manufaktur diantaranya yang di temui pada PT.AKR Corporindo, Tbk menunjukan bahwa sebelum dan sesudah informasi pembagian deviden di terima pasar, harga saham berfluktuasi setelah informasi pengumuman deviden diterima, kondisi ini bertentangan dengan teori yang menunjukan bahwa ketika informasi di terima, pasar merespon dengan cepat dan mendorong harga naik.

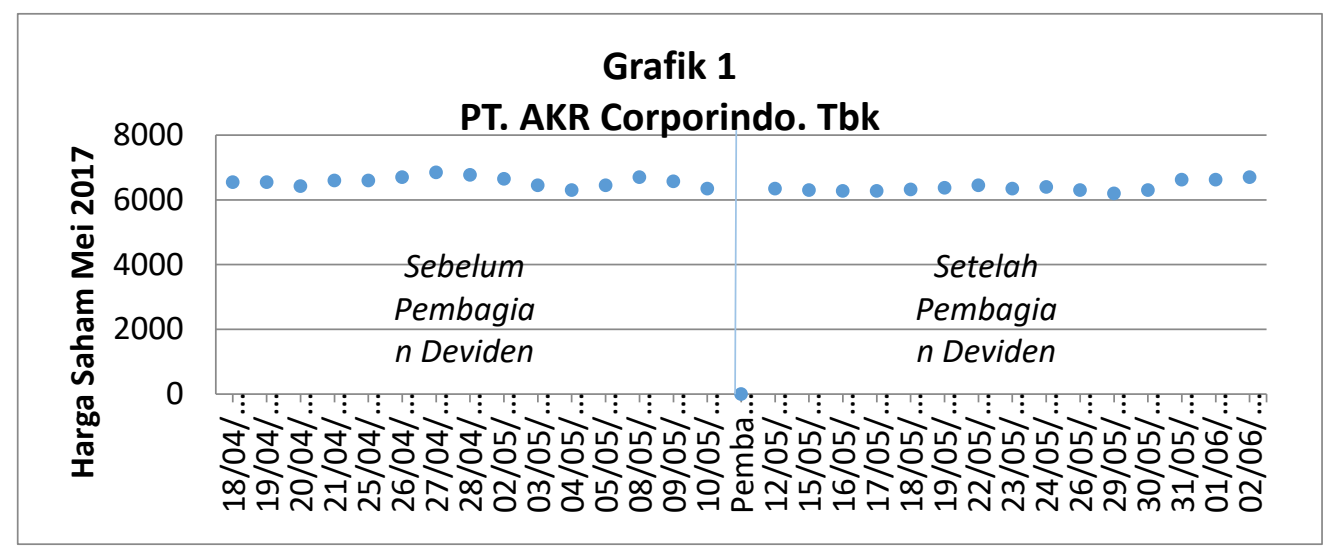

Sumber : Data Diolah Peneliti

Penelitian sebelumnya mengenai efisiensi pasar modal dalam bentuk semi strong oleh I Gusti Ngurah Angung Putra Dwipayana Dkk(2016) dan Novita Sari (2015) terdapat abnormal return yang berarti pasar tidak efisien, sedangkan Vivi Ariyani (2016) dan Ketut Setya Pramana Dkk (2016) tidak terdapat abnormal return yang berarti pasar efisien, sesuai dengan teori.

Berdasarkan uraian di atas, maka permasalahan dalam penelitian ini adalah apakah terdapat abnormal return yang positif pada hari pengumuman dan di sekitar tanggal pengumuman dividen. Setelah pertanyaan penelitian tersebut dapat terjawab, maka langkah selanjutnya adalah melihat kecepatan reaksi pasar dalam merespon pengumuman dividen. Langkah ini diperlukan untuk mengetahui apakah pasar modal Indonesia sudah efisien setengah kuat secara informasi atau belum terhadap pengumuman dividen oleh perusahaan Manufaktur.

\section{KERANGKA PEMIKIRAN TEORITIS}

\section{Konsep Efisiensi Pasar Modal}

Menurut Mamduh Hanafi (2016), pasar dikatakan efisien jika harga mencerminkan semua informasi yang relevan. Implikasi teori tersebut adalah investor tidaak bisa memperoleh keuntungan abnormal yang konsisten. Jika seorang investor ingin memperoleh keuntungan abnormal yang konsisten, maka ia harus menggunakan informasi yang belum tercermin dalam harga.

Menurut Suad Husnan (2015), pasar modal yang efisien di definisikan sebagai pasar yang harga sekuritas-sekuritasnya telah mencerminkan semua informasi yang relevan. Semakin cepat informasi baru tercermin pada harga sekuritas, semakin efisien pasar modal tersebut. Dengan demikian akan sangat sulit (atau bahkan hampir tidak mungkin) bagi para pemodal untuk memperoleh tingkat keuntungan diatas normal secara konsisten dengan melakukan transakasi perdagangan di bursa efek. Efisiensi dalam artian ini sering juga disebut sebagai efisiensi informasional. 
Dari berbagai definisi yang ada, konsep pasar efisien sangat berhubungan dengan ketersediaan informasi. Pasar dikatakan efisien apabila nilai sekuritas setiap waktu mencerminkan semua informasi yang tersedia, yang mengakibatkan harga suatu sekuritas berada pada tingkat keseimbangannya. Harga keseimbangan suatu sekuritas mengakibatkan tidak akan adanya kesempatan yang diperoleh investor untuk mendapatkan return yang abnormal dari selisih harga sekuritas saham.

Hartono (2013:569) memberikan beberapa ciri-ciri dari pasar efisien sebagai berikut:

1. Investor adalah penerima harga (price takers), yang berarti bahwa sebagai pelaku pasar, investor seorang diri tidak dapat mempengaruhi harga dari suatu sekuritas.

2. Informasi tersedia luas kepada semua pelaku pasar pada saat yang bersamaan dan harga untuk memperoleh informasi tersebut murah.

3. Informasi dihasilkan secara acak (random) dan tiap-tiap pengumuman informasi sifatnya random satu dengan yang lainnya sehingga investor tidak dapat memprediksi kapan emiten akan mengumumkan informasi yang baru.

4. Investor bereaksi dengan menggunakan informasi secara penuh dan cepat, sehingga harga sekuritas berubah dengan semestinya mencerminkan informasi tersebut untuk mencapai keseimbangan yang baru.

Hartono (2013:571) juga memberikan beberapa ciri-ciri dari pasar yang tidak efisien yaitu jika kondisi-kondisi berikut terjadi:

1. Terdapat sejumlah kecil pelaku pasar yang dapat mempengaruhi harga dari sekuritas.

2. Harga dari informasi adalah mahal dan terdapat akses yang tidak seragam antara pelaku pasar yang satu dengan yang lainnya terhadap suatu informasi.

3. Informasi yang disebarkan dapat diprediksi dengan baik oleh sebagian dari pelaku-pelaku. Investor adalah individual-individual yang lugas (naive investor) dan tidak canggih.

Konsep pasar efisien ini memang perlu dibahas dan di teliti karena merupakan konsep dasar yang bisa membantu kita memahami bagaimana sebenarnya mekanisme harga yang terjadi di pasar. Untuk memudahakan penelitian tetang efisiensi pasar, Fama (1970), mengklasifikasikan bentuk pasar yang efisien ke dalam tiga efficient market hypotesis $(\mathrm{EMH})$, sebagai berikut :

\section{Efisien dalam bentuk lemah (weak form)}

Pasar efisien dalam bentuk lemah berarti semua informasi di masa lalu (historis) akan tercermin dalam harga yang terbentuk sekarang. maka infomasi historis tersebut (seperti harga dan volume perdagangan, serta peristiwa dimasa lalu) tidak bisa lagi digunakan untuk memprediksi perubahan harga di masa yang datang, karena sudah tercermin pada harga saat ini. Untuk itu investor tidak akan bisa memprediksi nilai pasar saham di masa datang dengan menggunakan data historis, sebagaimana di lalukan dalam analisis teknikal. (Tandelin 2010:223).

\section{Efisiensi dalam bentuk setengah kuat (semi strong).}

Pasar efisien dalam bentuk setengah kuat berarti harga pasar saham yang terbentuk sekarang telah mencerminkan informasi historis di tambah dengan semua infomasi yang di publikasikan (seperti earning, deviden, pengumuman stock split, penerbitan saham baru, kesulitan keuangan yang di alami perusahaan, dan peristiwa terpublikasi lainnya yang berdampak pada aliran kas perusahaan dimasa datang). Pada pasar efisien bentuk setengah kuat, abnormal return hanya terjadi di seputar pengumuman suatu peristiwa sebagai representasi dari respon pasar terhadap pengumuman tersebut. Suatu pasar dikatakan efisien dalam bentuk setengah kuat bila informasi terserap atau di respon dengan cepat oleh pasar (dalam satu hingga dua spot waktu atau hari diseputar pengumuman). Abnormal return yang terjadi berkepanjangan (lebih dari tiga spot waktu) mencerminkan respon pasar terlambat dalam menyerap atau menginterpretasi infomasi, dan dengan demikian pasar dianggap tidak efisien dalam bentuk setengah kuat. (Tandelin 2010:223)

\section{Efisiensi dalam bentuk kuat (strong form).}

Pasar efisien dalam bentuk kuat berarti harga pasar saham yang terbentuk sekarang telah mencerminkan infomasi historis dan semua informasi yang di publikasikan di tambah dengan 
infomasi yang tidak di publikasikan. Pada pasar efisien bantuk kuat tidak akan ada seorang investor mana pun yang bisa memperoleh abnormal return. (Tandelin 2010:223).

Tujuan Fama (1970) mengklasifikasikan pasar efisien menjadi tiga bentuk ini bertujuan untuk mempermudah penelitian-penelitian yang dilakukan terhadap efisiensi pasar (Tandelilin, 2010:223). Pada tahun 1991, Fama melakukan penyempurnaan atas klasifikasi efisiensi pasar tersebut. Efisiensi pasar bentuk lemah disempurnakan menjadi suatu klasifikasi yang lebih bersifat umum untuk menguji return prediktabilitas (return predictability). Pada klasifikasi ini, informasi mengenai pola return sekuritas, seperti pola return lebih tinggi di bulan Januari dan hari Jum'at yang dimanfaatkan oleh investor untuk memperoleh keuntungan yang abnormal. Sedangkan efisiensi bentuk setengah kuat diubah menjadi studi peristiwa (event studies), dan pengujian efisiensi pasar dalam bentuk kuat disebut sebagai pengujian informasi rahasia (private information) (Tandelilin, 2010:224).

\section{Gambar 1}

Sumber Data dalam Kaitannya dengan Pandangan seseorang Tentang Efisien Tidaknya sebuah Pasar Modal

\begin{tabular}{|c|c|c|c|c|}
\hline \multicolumn{5}{|c|}{ Tingkat Informasi } \\
\hline $\begin{array}{l}\text { Semua } \\
\text { Informasi }\end{array}$ & $\begin{array}{l}\text { Data Publik, } \\
\text { Data Pribadi, } \\
\& \text { data Harga } \\
\text { masa lalu }\end{array}$ & $\begin{array}{l}\text { Data Publik, } \\
\text { Data Pribadi, } \\
\& \text { bukan data } \\
\text { Harga masa } \\
\text { lalu }\end{array}$ & $\begin{array}{l}\text { Hanya } \\
\text { data pribadi }\end{array}$ & $\begin{array}{l}\text { Tidak ada } \\
\text { informasi }\end{array}$ \\
\hline $\begin{array}{l}\text { Tidak } \\
\text { Efisien }\end{array}$ & Efisien Lemah & $\begin{array}{l}\text { Efisien } \\
\text { setengah kuat }\end{array}$ & Efisien kuat & $\begin{array}{l}\text { Efisien } \\
\text { sempurna }\end{array}$ \\
\hline
\end{tabular}

\section{Studi Peristiwa (Event Study)}

Studi peristiwa (event study) merupakan studi yang mempelajari reaksi pasar terhadap suatu peristiwa (event) yang informasinya dipublikasikan sebagai suatu peristiwa (Jogiyanto, 2015: 623). Apabila pengumuman mengandung informasi (information content), maka diharapkan akan terjadi reaksi oleh pasar pada saat pengumuman tersebut diterima oleh pasar. Reaksi pasar ditandai dengan terjadinya perubahan harga sekuritas yang bersangkutan. Reaksi seperti ini bisa diukur dengan menggunakan return sebagai nilai perubahan harga atau dengan menggunakan abnormal return. Apabila abnormal return digunakan untuk mengukur reaksi tersebut maka suatu pengumuman yang mempunyai kandungan informasi diperkirakan dapat memberikan abnormal return kepada pasar. Sebaliknya apabila pengumuman tidak mengandung informasi maka dapat dikatakan tidak memberikan abnormal return pada pasar. Event study dapat digunakan untuk menguji kandungan (information content) dari suatu pengumuman dan dapat juga digunakan untuk menguji efisiensi pasar bentuk setengah kuat. Abnormal Return atau Return tidak normal menjadi focus dalam studi peristiwa yang mengamati harga atau efisiensi pasar.

\section{Investor}

Pihak-pihak yang melakukan investasi disebut Investor. Investor pada umumnya di golongkan menjadi dua, yaitu: Investor Individu (Retail Investor) dan Investor Institusional (Instutional Investor). Investor individu terdiri dari individu-individu yang melakukan investasi. Sedangkan Investasi Institusional biasanya terdiri dari perusahaan-perusahaan asruransi, lembaga penyimpanan dana, lembaga dana pensiun, maupun perusahaan investasi (Tandelin $2010: 2-3$ ). Dan investasi bertujuan untuk meningkatakan kesejahterahan investor. (Tandelin 2010 : 7).

\section{Dasar Keputusan Investasi}


Dasar keputusan investasi terdiri dari tingkat return harapan, tingkat resiko serta hubungan antara return dan resiko. Berikut ini akan di bahas masing-masing dari keputusan investasi tersebut.

Return, alasan utama orang berinvestasi adalah untuk mendapatkan keuntungan. Return harapan investor dari investasi yang dilakukan merupakan kompensasi atas biaya kesempatan (opportunity cost) dari resiko penurunan daya beli akibat adanya pengaruh inflasi. Dalam konteks menejemen investasi perlu di bedakan antara return harapan dan return aktual. Return harapan merupakan tingkat return yang diantisipasi investor dimasa datang. Sedangkan return yang terjadi atau return aktual merupakan tingkat return yang diperoleh investor pada masa lalu. (Tandelin 2010 : 9-10).

Sumber-sumber return investasi terdiri dari dua komponen utama, yaitu yield dan capital gain(loss). Yield merupakan komponen return yang mencerminkan aliran kas atau pendapatan yang di peroleh secara periodic dari suatu investasi. Capital Gain(Loss) sebagai komponen kedua dari return merupakan kenaikan(Penurunan) harga suatu surat berharga , yang bisa memberikan keuntungan(kerugian) bagi investor. Dalam kata lain, capital gain(Loss) bisa juga diartikan sebagai perubahan harga sekuritas. (Tandelin 2010 : 102). Resiko, ada hal penting yang harus selalu dipertimbangkan dalam berinvestasi, yaitu berapa besar resiko yang harus ditanggung dari investasi tersebut. Umumnya semakin besar resiko, maka semakin besar pula tinggkat return harapan.

\section{Hubungan Tingkat Resiko dan Return Harapan}

Hubungan antara resiko dan tingkat return harapan merupakan hubungan yang bersifat searah dan linier. Artinya, semakin besar resiko suatau asset, semakin besar pula return harapan atas asset tersebut, demikian sebaliknya. (Tandelin 2010:11).

\section{Sekuritas di pasar Ekuitas}

Sekuritas yang di perdagangkan di pasar bersifat ekuitas Indonesai adalah saham baik saham biasa maupun saham preferen serta bukti right dan waran. Dari keempat sekuritas ini saham biasa merupakan sekuritas terpenting dan paling dikenal oleh masyarakat Indonesia. Pemegang saham biasa memiliki hak klaim atas penghasilan dan aktiva perusahaan. Apabila perushaan menghasilkan laba dalam menjalanka bisnisnya, maka sebagian atau seluruh laba dapat dibagikan kepada pemiliknya, yaitu pemegang saham sebagai deviden.

\section{Deviden}

\section{Pengertian Deviden}

Menurut Nikiforous (2013), pengertian dividen adalah pembayaran tunai yang dilakukan oleh perseroan kepada para pemegang saham. Dividen tersebut merepresentasikan pemegang saham terhadap penerimaan langsung atau tak langsung atas investasi mereka di perusahaan. Mengacu pada pengertian dividen di atas, berikut ini beberapa macam dividen dalam bisnis: (a).Cash Dividend adalah metode pembayaran keuntungan secara tunai dan dikenai pajak hanya pada di tahun saat pengeluarannya. (b). Stock Dividend adalah metode pembagian dividen yang dilakukan melalui penambahan jumlah saham namun mengurangi nilai setiap saham dengan tujuan untuk tidak mengubah kapitalitas pasar. (c).Property Dividend adalah metode pembagian dividen yang dibayarkan melalui bentuk aset seperti pada bisnis properti, namun metode ini jarang digunakan dalam bisnis. (d).Dividen interim adalah dividen yang diumumkan serta dibayarkan sebelum perusahaan selesai membukukan keuntungan tahunan. (e).Scrip Dividen adalah pembagian dividen kepada para pemegang saham dalam bentuk janji tertulis dimana perusahaan akan membayarkan sejumlah kas di masa mendatang. Dividen scrip bisa berbentuk bunga atau tidak berbunga, dan bisa diperjualbelikan kepada para pemegang saham lainnya. (f).Dividen Likuidasi adalah dividen yang dikeluarkan saat dewan direksi akan melakukan likuidasi bisnis dan mengembalikan semua aset bersih yang tersisa kepada para pemegang saham dalam bentuk uang tunai.

Terdapat lima tujuan pembagian dividen. Pertama, pembagian dividen dilakukan untuk memaksimumkan kemakmuran para pemegang saham, karena sebagian investor 
menanamkan dananya di pasar modal untuk memperoleh dividen dan tingginya dividen yang dibayarkan akan memengaruhi harga saham. Para investor percaya bahwa tingginya dividen yang dibayarkan berarti bahwa perusahaan memiliki prospek bagus di masa yang akan datang. Kedua, pembagian dividen dilakukan untuk menunjukkan likuiditas perusahaan. Sebagian perusahaan memberikan dividen dalam jumlah tetap untuk setiap periode karena perusahaan ingin diakui oleh investor bahwa perusahaan yang bersangkutan mampu menghadapi gejolak ekonomi dan mampu memberikan hasil kepada investor.

Ketiga, pembagian dividen dilakukan karena sebagian investor beranggapan bahwa risiko dividen lebih rendah dibanding risiko capital gain. Keempat, pembagian dividen dilakukan untuk memenuhi kebutuhan para pemegang saham terhadap pendapatan tetap yang digunakan untuk keperluan konsumsi. Kelima, pembagian dividen dilakukan karena dividen dapat digunakan sebagai alat komunikasi antara manajer dan pemegang saham. Para investor sering tidak mengetahui informasi secara keseluruhan tentang kondisi internal perusahaan, sehingga melalui dividen maka investor dapat mengetahui pertumbuhan perusahaan dan prospek perusahaan di masa yang akan datang.

Menurut Tatang Ary Gumanti (2013:19) proses pembayaran dividen antara lain:

\section{a. Dividens declaration date}

Tanggal pertama kali dewan direksi mengumumkan pembayaran dividen disebut sebagai tanggal deklarasi dividen (dividens declaration date), yang merupakan tanggal dimana dewan direksi atau hasil dari RUPS mendeklarasikan jumlah dividen tunai yang akan dibayarkan perusahaan untuk suatu periode waktu tertentu.

b. Tanggal cum-dividend (cum-dividend date)

Tanggal cum-dividend merupakan tanggal hari terakhir perdagangan saham yang masih melekat hak untuk mendapatkan dividen, baik dividen tunai maupun dividen saham.

c. Tanggal eks-dividen (ex-dividend date)

Tanggal eks-dividen merupakan tanggal pada saat hak atas dividen periode berjalan dilepaskan dari sahamnya. Investor yang membeli saham dalam periode ini tidak memiliki hak untuk menerima dividen.

d. Tanggal pencatatan dalam daftar pemegang saham (date of record)

Tanggal ini merupakan tanggal seseorang harus terdaftar sebagai pemegang saham perusahaan publik atau emiten, sehingga ia mempunyai hak memperoleh dividen yang diperuntukkan bagi pemegang saham.

e. Tanggal pembayaran (payment date)

Tanggal pembayaran merupakan saat pembagian dividen oleh perusahaan kepada pemegang saham yang telah mempunyai hak atas dividen.

Menurut Syamsuddin (2011), dividen merupakan pembayaran yang diberikan kepada pemilik perusahaan atau pemegang saham atas modal yang mereka tanamkan di dalam perusahaan. Dalam hubungannya dengan jumlah pajak yang dibayarkan, maka pembayaran dividen berbeda dengan pembayaran bunga karena dividen tidak dapat mengurangi jumlah pajak yang dibayar oleh perusahaan. Berdasarkan beberapa pengertian di atas, maka dapat disimpulkan bahwa dividen merupakan salah satu kebijakan yang penting dalam perusahaan karena menyangkut pemegang saham yang notabene merupakan sumber modal dari perusahaan tersebut.

Saham

\section{Pengertian Saham.}

Saham dapat didefinisikan sebagai tanda penyertaan atau kepemilikan seseorang atau badan dalam suatu perusahaan atau perseroan terbatas. Wujud saham adalah selembar kertas yang menerangkan bahwa pemilik kertas tersebut adalah pemilik perusahaan yang menerbitkan surat berharga tersebut. Porsi kepemilikan ditentukan oleh seberapa besar penyertaan yang ditanamkan di perusahaan tersebut (Darmadji dan Fakhruddin, 2012). Sedangkan 
menurut Hadi (2013) pengertian saham adalah surat berharga yang dapat dibeli atau dijual oleh perorangan atau lembaga dipasar tempat surat tersebut diperjualbelikan.

Terdapat tiga metode yang secara luas digunakan dalam penelitian studi peristiwa. (i). Model-model statistika : terdapat dua model penyesuaian yang paling umum digunakan, yaitu : model disesuaikan rata-rata (mean adjust model) dan model pasar (market model). (ii). Model disesuaikan dengan pasar (market adjusted model) . (iii) Model-model ekonomika (economic models) terdapat dua model yang secara luas digunakan, yaitu : capital asset pricing model (CAPM) dan arbitrage pricing theory (APT).

\section{Abnormal Return.}

Abnormal return dalam Bahasa Indonesia adalah return tidak normal.Maksudnya adalah kelebihan return yang sesungguhnya terhadap return normal. Menurut Jogiyanto (2013), return tak normal merupakan return ekspektasian atau return yang diharapkan investor. Dan abnormal return merupakan selisih antara return sesungguhnya dengan return ekspektasi. Return sesungguhnya adalah return yang terjadi pada waktu ke-t yang merupakan selisih harga sekarang relatif terhdap harga saham sebelumnya. Sedangkan return ekspekstasi merupakan return yang harus diestimasi.

Sedangkan menurut Tandelilin (2010), abnormal return merupakan selisih actual return dengan expected return yang dapat terjadi sebelum informasi diterbitkan atau telah terjadi kebocoran informasi setelah informasi diterbitkan. Abnormal Return atau excess return merupakan kelebihan dari return sesungguhnya terjadi terhadap return normal dengan rumus sebagai berikut;

$$
\text { ARit }=\text { Rit }- \text { Rcapm }
$$

Keterangan :

$$
\begin{array}{ll}
\text { ARit } & : \text { Abnormal Return saham i pada hari ke }-\mathrm{t} \\
\text { Rit } & : \text { Actual Return saham i pada hari ke }-\mathrm{t} \\
\text { Rcapm } & : \text { Tingkat return yang di isyaratkan investor pada saham } i
\end{array}
$$

\section{Kerangka Berfikir}

Berdasarkan landasan teoritis dan hasil penelitian terdahulu, maka kerangka pikir dalam penelitian ini adalah sebagai berikut:

1. Kandungan informasi inisiasi dividen

Sebuah peristiwa bernilai ekonomis apabila memiliki kandungan informasi. Kandungan informasi inisiasi dividen dalam penelitian ini ditunjukkan dengan ada atau tidaknya reaksi pasar di sekitar ex-dividend date inisiasi dividen tersebut. Reaksi pasar timbul akibat adanya informasi yang beredar dan diserap oleh pasar. Keadaaan ini sesuai dengan teori sinyal dividen (dividend signaling theory) yang menyatakan bahwa pengumuman dividen merupakan sumber informasi dan sekaligus sebagai sinyal bagi prospek masa depan perusahaan dan dapat dijadikan sebagai pertimbangan dalam pengambilan keputusan investasi. Perusahaan yang melakukan inisiasi dividen biasanya merupakan sinyal positif bagi investor. Reaksi pasar terhadap inisiasi dividen dapat diukur dengan menggunakan return sebagai nilai perubahan harga atau dengan menggunakan abnormal return. Reaksi dapat dilihat sebagai berikut: 


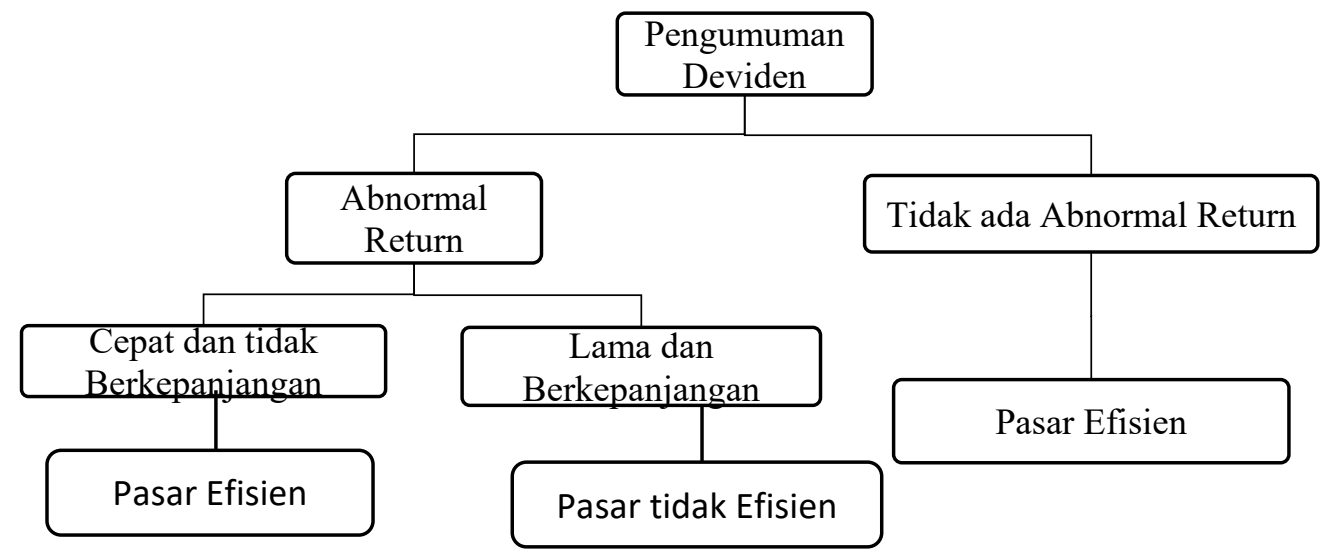

Gambar 2 Kerangka Berfikir

\section{Hipotesis}

Hipotesis adalah jawaban sementara terhadap penelitian yang keberadaannya harus diuji secara empiris. Hipotesis memberikan keterangan sementara mengenai fenomena yang diteliti, dalam hal ini adalah hubungan antara variabel bebas dan variabel terikat. Maka dapat dirumuskan hipotesisnya sebagai berikut:

Ho1 : Terdapat Abnormal Return sebelum dan sesudah peristiwa pengumuman deviden.

Ho2 : Perusahaan manufaktur yang terdaftar di Bursa efek Indonesia sudah efisien dalam bentuk setengah kuat.

\section{METODOLOGI}

\section{Populasi dan Sampel}

Populasi dalam penelitian ini adalah perusahaan Manufaktur yang terdaftar di Bursa Efek Indonesia tahun 2014-2017 (4 tahun) .Dan metode yang di gunakan untuk penentuan sampel adalah metode purposive sampling, merupakan tehnik penentuan sampel yang menggunakan pertimbangan atau kriteria tertentu (Sugiyono, 2010;122). Kriteria sampel dalam penelitian ini yaitu ;

a. perusahaan Manufaktur yang terdaftar pada Bursa Efek Indonesia.

b. melakukan pembayaran deviden secara konsisten selama 4 tahun terakhir yaitu tahun $2014-$ 2017.

c. Saham perusahaan yang menjadi sampel penelitian merupakan saham yang aktif diperdagangkan.

d. Perusahaan tidak sedang melakukan company action lain seperti right issue, pemberian saham bonus, stock dividend, stock split, merger dan akuisisi selama periode jendela (event window) untuk menghindari adanya confounding effect yang dapat memengaruhi hasil penelitian.

\section{Desain Penelitian}

Penelitian ini merupakan event study yang mengamati dampak dari pengumuman infomasi terhadap harga sekuritas. Penelitian event studies umumnya berkaitan dengan seberapa cepat suatu infomasi yang masuk kepasar dapat tercermin pada harga saham.

\section{Jenis dan Sumber Data}

Jenis data yang digunakan dalam penelitian ini adalah data sekunder.Data diperoleh melalaui pengumpulan data dengan cara melakukan pengamatan dan mencatat dengan cara 
mengakses melalui $\underline{w w w . i d x . c o . i d}$ dan $\underline{w w w . f i n a n c e . y a h o o . c o m}$ data tersebut diperoleh dalam bentuk closing price saham pada perusahaan Manufaktur di Bursa Efek Indonesia periode 20142017.

\section{Metode Analisis Data}

Teknik analisis data yang digunakan dalam penelitian ini untuk menyelesaikan masalahmasalah dalam penelitian ini adalah dengan urutan sebagai berikut: Melakukan perhitungan actual return, return pasar, rata-rata abnormal return, abnormal return, dan signifikansi abnormal return dengan Model Economica CAPM (Capital Asset Pricing Model) untuk masing-masing emiten adapun langkahnya-langkahnya sebagai berikut :

Prosedur Studi Peristiwa, Metodologi penelitian studi peristiwa konvensional mengikuti prosedur sebagai berikut ;

a. Mengidentifikasi bentuk, efek, dan waktu peristiwa (i) peristiwa apa yang memiliki nilai informasi; (ii) apakah nilai peristiwa informasi memiliiki efek negative atau positif terhadap return tak normal perusahaan tertentu; dan (iii) bilamana peristiwa terjadi atau di publikasikan.

b. Menentukan rentan waktu studi peristiwa termasuk periode peristiwa. Periode peristiwa (T- $n$ Hingga $\mathrm{T}+n$ ) adalah periode seputar peristiwa (T0) yang di gunakan untuk menguji perubahan return tak normal.

Periode jendela (event window) terdiri dari 31 hari yaitu 15 hari sebelum ex-dividend date (t15), 1 hari pada ex-dividend date $(\mathrm{t}=0)$ dan 15 hari sesudah ex-dividend date $(\mathrm{t}+15)$.

c. Menentukan metode penyesuaian return yang di gunakan untuk menghitung return tak normal. Dan peneliti memilih Economics Model CAPM (Capital Asset Pricing Model).

d. Mengahitung return tak normal disekitar periode peristiwa ( beberapa waktu sebelum dan sesudah pengumuman peristiwa terjadi) Dan langkah-langkahnya sebagai berikut ;

Perhitnugan abnormal return dengan CAPM(Capital Asset Pricing Model) market model return untuk masing-masing emiten (Eduardus Tandelilin, 2014:197) :

$$
\text { Rumus : } k_{i}=R_{f}+\beta_{i}\left[E\left(R_{m}\right)-R_{f}\right]
$$

Keterangan:

$k_{i} \quad$ : Tingkat return yang di isyaratkan investor pada sekuritas $i$

$\mathrm{E}(\mathrm{Rm}) \quad:$ Return portofolio pasar yang di harapkan

$\beta_{i} \quad$ : Koefisien beta sekuritas $i$

Rf : Tingkat return bebas resiko

Cara menghitung return tak normal;

1. $R f$ : Tingkat return bebas resiko

Tingkat return bebas resiko dalam penelitaian ini adalah SDBI (Sertifikat Deposito Bank Indonesia) per tahun. Dan peneliti membagi dengan 360 hari untuk menyesuaikan dengan data penelitian.

2. $\beta_{i} \quad$ : Koefisien beta sekuritas $i$

Koefisien beta sekuritas dalam penelitaian ini di hitung dengan mengunakan Slope dalam Microsft Excel.

3. $\mathrm{E}(\mathrm{Rm})$ : Return portofolio pasar yang di harapkan

Return portofolio pasar yang di harapkan dihitung dengan cara (Return Sekuritas x Return Market). 


\section{Cara menghitung Return Sekuritas (Actual Return) :}

Menghitung actual return (return sesungguhnya), (Jogiyanto, 2015:265):

Rumus :

$$
R_{i t}=\frac{R_{i t}-P_{i, t-1}}{P_{i, t-1}}
$$

Keterangan:

Rit : Return sesungguhnya yang terjadi untuk sekuritas ke-I pada periode peristiwa ke-t.

$\mathrm{Pi}, \mathrm{t}$ : Harga sekarang relatif.

Pi,t-1 : Harga sebelumnya.

Cara menghitung Return Pasar (Return Market) :

Menghitung return pasar harian (Jogiyanto, 2015:648):

Rumus : $\quad R_{m t}=\frac{I H S G_{t}-I H S G_{t-1}}{I H S G_{t-1}}$

Keterangan:

Rmt : Return pasar pada waktu ke-t

IHSG $t \quad:$ Indeks Harga Saham Gabungan hari ke-t

IHSGt-1 : Indeks Harga Saham Gabungan hari ke-t-1

e. Menghitung rata-rata return tak normal.

Cara menghitung Return tak normal rata-rata dan return tak normal komulatif :

Return rak normal rata-rata (Tandelilin,2010:575);

$$
\text { Rumus } \quad: \quad \quad R T N_{t}=\frac{\sum_{i-1}^{n} R T N i t}{k}
$$

Keterangan :

RTNt : Return tak normal rata-rata pada waktu ke t

$\mathrm{K}$ : jumlah sekuritas

Return tak normal komulatif (Tandelilin,2010:575);

$$
\text { Rumus : } R T K N_{i}=\sum_{t=-n}^{t=+n} R T N i t
$$

f. Merumuskan hipotesis statistis.

dapat dirumuskan hipotesisnya sebagai berikut:

Ho1 : Terdapat Abnormal Return sebelum dan sesudah peristiwa pengumuman deviden.

Ho2 : Perusahaan manufaktur yang terdaftar di Bursa Efek Indonesia sudah efisien dalam bentuk setengah kuat.

g. Menguji return tak normal apakah ada perbedaan sebelum dan sesudah pengumuman peristiwa terjadi. Pengujian yang dapat dilakukan dalam penelitian ini adalah uji beda bisa menggunakan statistic parametric atau non parametric tergantung dari data yang digunakan apakah terdistribusi normal atau tidak. Berikut uji beda yang dapat di gunakan :

i. Uji Sample t-Test atau uji T sampel independent merupakan uji parametrik yang digunakan untuk menguji apakah ada perbedaan rata-rata sempel yang berhubungan, uji ini di gunakan jika data penelitian yang di gunakan terdistribusi normal dan hal ini di buktikan setelah dilakaukan uji normalitas data dengan uji Kolmogrov Smirnov.

\section{Metode Pengumpulan Data}

Dalam metode pengumpulan data, peneliti melakukan dua tahap yaitu:

a. Tahap pertama dilakukan melalui studi pustaka yakni pengumpulan data pendukung berupa literature dan penelitian terdahulu. 
b. Tahap kedua dilakukan pengumpulan data menggunakan metode dokumentasi. Metode dokumentasi yang digunakan dalam penelitian ini dilakukan dengan mengumpulkan data yang diperoleh dari situs website resmi yang telah terpercaya.

\section{Jenis Data}

Jenis data yang digunakan dalam penelitian ini adalah data sekunder yaitu data yang telah diolah lebih lanjut dan telah disajikan oleh pihak lain. Data Bank Indonesia mengenai inflasi, nilai tukar rupiah dan BI rate. Dengan periode 1 Januari 2018- 15 Juli 2018 untuk masing-masing variabel.

\section{Metode Analisis Data}

Pengujian ini menggunakan analisis deskriptif, pengujian asumsi klasik, analisis regresi dan pengujian hipotesis.

\section{Analisis Deskriptif}

Merupakan penelitian yang bertujuan untuk membuat deskripsi atau gambaran mengenai suatu data agar dapat dipahami oleh pembaca. Analisis ini menjelaskan berbagai karakteristik data ratarata (mean), jumlah (sum), standar deviation, variance, nilai minimum dan maximum.

\section{Uji Normalitas Data}

Uji normalitas data terlebih dahulu dilakukan untuk mengetahui apakah data berdistribusi normal atau tidak. Normalitas data merupakan syarat pokok yang harus dipenuhi dalam analisis parametrik. Normalitas data merupakan hal yang paling penting karena dengan data yang terdistribusi normal, maka data tersebut dianggap dapat mewakili populasi. Salah satu metode uji normalitas adalah dengan metode Liliefors dengan Kolmogorov-Smirnov dan Shapiro-Wilk. Untuk metode Kolmogorov-Smirnov, kriteria pengujiannya adalah sebagai berikut :

Jika signifikasi $<0,05$ maka data tidak berdistribusi normal.

Jika signifikasi $>0,05$ maka data berdistribusi normal.

\section{ANALISIS DAN PEMBAHASAN}

Perusahaan yang diteliti adalah perusahaan manufaktur selama 4 tahun,. Pemilihan sampel dalam penelitian ini ditentukan dengan metode purposive sampling dengan beberapa kriteria. Pengambilan sampel penelitian dapat digambarkan pada tabel di bawah ini :

\section{Tabel 1}

Proses Pemilihan Sampel Tahun 2014 - 2017

\begin{tabular}{|l|l|}
\hline \multicolumn{1}{|c|}{ Kreteria Sampel } & \multicolumn{1}{c|}{ Keterangan } \\
\hline Total Perusahaan Manufaktur yang Terdaftar di BEI & 144 Perusahaan \\
\hline $\begin{array}{l}\text { Perusahaan yang tidak konsisten membagikan } \\
\text { deviden }\end{array}$ & 118 Perusahaan \\
\hline Perusahaan yang konsisten membagikan deviden & 26 Perusahaan \\
\hline
\end{tabular}

Sumber : Data diolah Peneliti

Dari 144 perusahaan manufaktur sebanyak 118 tidak membagikan dividen secara konsisten,maka hanya 26 perusahaan yang memenuhi kriteria sebagai sampel penelitian.

Tabel 2

Statistik Deskriptif Avarage Abnormal Return Descriptive Statistics

\begin{tabular}{|l|r|r|r|c|r|}
\hline & \multicolumn{1}{|c|}{$\mathrm{N}$} & Minimum & Maximum & Mean & Std. Deviation \\
\hline AAR & 26 & -.01182 & .02115 & .0058442 & .00925938 \\
Valid N (listwise) & 26 & & & & \\
\hline
\end{tabular}

Sumber : Data Diolah peneliti 
Berdasarkan tabel 4.3 dapat diperoleh gambaran bahwa selama periode tahun 2014-2017 dengan 26 sampel perusahaan terdapat nilai Average Abnormal Return (AAR) paling rendah (minimum) sebesar -0,01182 diperoleh para investor yang berinvestasi pada perusahaan (KLBF), sedangkan nilai Average Abnormal Return (AAR) tertinggi (maximum) sebesar 0,02115 diperoleh para investor yang berinvestasi pada perusahaan (SRIL) dapat di lihat pada lampiran 5 Tabel Avarage Abnormal Return. Nilai rata-rata Average Abnormal Return (AAR) sebesar 0,0058422 dan tingkat penyimpangan sebaran data (standard deviation) nilai Average Abnormal Return (AAR) sebesar 0,00925938.

Untuk melihat pergerakan Average Abnormal Return (AAR) selama periode jendela, di bawah ini ditampilkan grafik pergerakan Average Abnormal Return (AAR) berdasarkan data-data hasil olahan peneliti.

\section{Grafik 2}

\section{Grafik Avarage Abnormal Return}

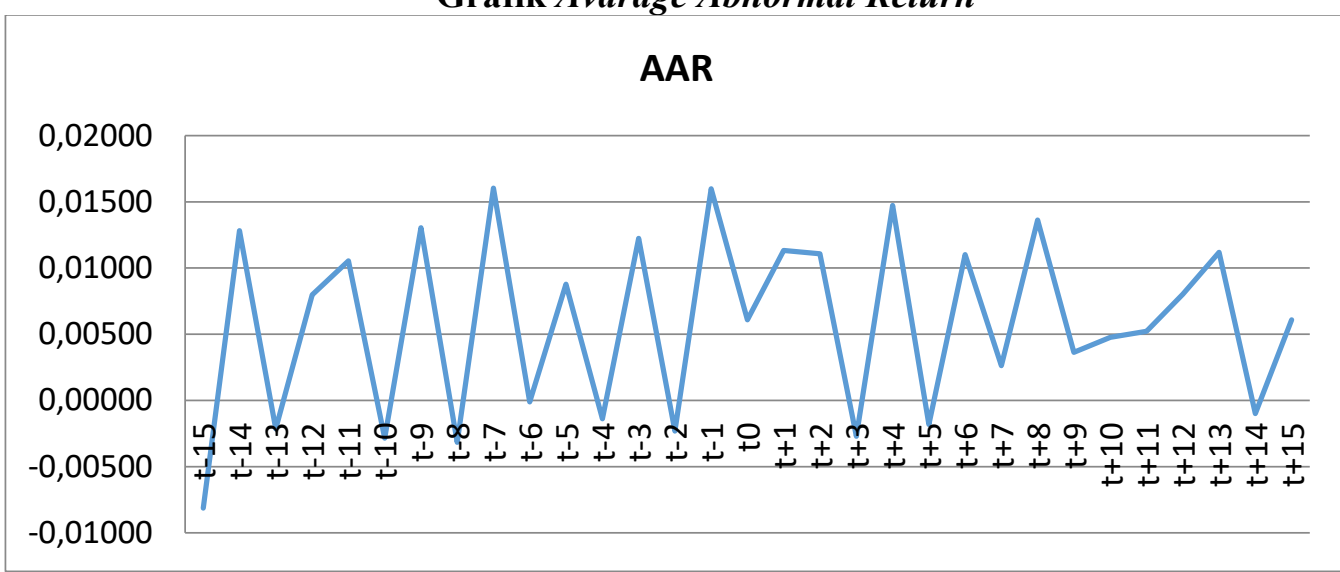

Sumber:Data Diolah Peneliti

Berdasarkan grafik 2 terlihat grafik untuk Average Abnormal Return (AAR) pada periode jendela yaitu 15 hari sebelum cum-dividend date, 1 hari pada cum-dividend date, dan 15 hari sesudah cum-dividend date. Grafik di atas terlihat fluktuatif yang ditunjukkan pada beberapa periode terdapat Average Abnormal Return (AAR) bertanda positif dan negatif,yang menunjukan ada indikasi informasi pengumuman dividen sudah sampai kepada investor,pada hari pengumuman reaksi pasar positif dan begitu juga dengan $\mathrm{t}+1$ dan $\mathrm{t}+2$.Secara keseluruhan, grafik tersebut menunjukkan kenaikan secara perlahan Average Abnormal Return (AAR) selama periode jendela.

\section{Uji Normalitas Data}

Pengujian terhadap pola distribusi data yang digunakan dalam penelitian diperlukan untuk mengetahui uji normalitas data yang lebih tepat dalam menganalisis hasil penelitian, yaitu apakah menggunakan analisis parametrik atau non-parametrik.

Berdasarkan hasil uji normalitas yang telah dilakukan menunjukkan bahwa data yang dipergunakan dalam penelitian ini normal. Hal ini ditunjukkan dengan nilai sig. Z hasil uji kolmogorov-smirnov test yang menunjukkan nilai lebih dari $0,05(5 \%)$, yaitu AAR (Avarage Abnormal Return) sebesar 0.905 (90\%), di lihat pada Tabel.4.4 
Tabel 3

Uji Normalitas data

One-Sample Kolmogorov-Smirnov Test

\begin{tabular}{|ll|r|}
\hline & & \multicolumn{1}{|c|}{ AAR } \\
\hline $\mathrm{N}$ & & 26 \\
Normal Parameters $^{\mathrm{a}}$ & Mean & $\ldots$ \\
& Std. Deviation & $\ldots$ \\
Most Extreme Differences & Absolute & .111 \\
& Positive & .111 \\
& Negative & .099 \\
Kolmogorov-Smirnov Z & & .566 \\
Asymp. Sig. (2-tailed) & & .905 \\
\hline
\end{tabular}

a. Test distribution is Normal.

Sumber : Data Diolah Peneliti

Data yang digunakan untuk penelitian dapat di simpulkan bahwa data terdistribusi normal, maka dari itu pengolahan data selanjutnya mengunakan Uji one sample t test,yaitu merupakan prosedur uji $t$ untuk sampel tunggal jika rata-rata suatu variabel tunggal dibandingkan dengan suatu nilai konstanta tertentu. Uji t dipakai jika jumlah data sampel di bawah 30. Syarat melakukan uji ini data harus kuantitatif dan terdistribusi normal.

Selain pengujian terhadap kandungan informasi, penelitian ini juga melakukan pengujian kecepatan reaksi pasar yang dilakukan dengan melihat seberapa cepat pasar bereaksi terhadap pengumuman dividen. Pasar dikatakan efisien apabila pasar bereaksi cepat dan tidak berkepanjangan dalam menyerap informasi dan menuju ke harga keseimbangan yang baru. Jika pasar bereaksi dengan cepat dan akurat terhadap suatu informasi yang masuk dan segera membentuk harga keseimbangan yang baru, maka kondisi pasar yang seperti ini yang disebut dengan pasar efisien (Hartono, 2013:547).

\section{Hipotesis Pengujian}

Dari hasi pengujian hipotesis yang dilakukan dengan uji One Simple T Test diperoleh hasil sebagai berikut:

\section{Uji One Simple T Test}

Tabel. 4

Hasil pengujian kandungan informasi disekitar tanggal pengumuman deviden

\begin{tabular}{|l|r|l|l|l|}
\hline $\begin{array}{c}\text { Periode } \\
\text { Pengamat } \\
\text { an }\end{array}$ & $\begin{array}{c}\text { Avarage } \\
\text { Abnormal } \\
\text { Return }\end{array}$ & t Hitung & $\begin{array}{c}\text { Sig }(2- \\
\text { tailed })\end{array}$ & \multicolumn{1}{|c|}{ Keterangan } \\
\hline $\mathrm{t}-15$ & -0.00813 & -1.301 & .205 & Tidak signifikan \\
\hline $\mathrm{t}-14$ & 0.01282 & 1.954 & .062 & Tidak signifikan \\
\hline $\mathrm{t}-13$ & -0.00214 & -.473 & .640 & Tidak signifikan \\
\hline $\mathrm{t}-12$ & 0.00798 & 1.256 & .221 & Tidak signifikan \\
\hline $\mathrm{t}-11$ & 0.01053 & 1.691 & .103 & Tidak signifikan \\
\hline $\mathrm{t}-10$ & -0.00286 & -.418 & .679 & Tidak signifikan \\
\hline $\mathrm{t}-9$ & 0.01304 & 1.768 & .089 & Tidak signifikan \\
\hline $\mathrm{t}-8$ & -0.00316 & -.230 & .820 & Tidak signifikan \\
\hline $\mathrm{t}-7$ & 0.01603 & 3.159 & .004 & Signifikan pada level 5\% \\
\hline $\mathrm{t}-6$ & -0.00012 & -.014 & .989 & Tidak signifikan \\
\hline $\mathrm{t}-5$ & 0.00879 & 1.297 & .206 & Tidak signifikan \\
\hline
\end{tabular}




\begin{tabular}{|l|r|l|l|l|}
\hline $\mathrm{t}-4$ & -0.00139 & -.161 & .873 & Tidak signifikan \\
\hline $\mathrm{t}-3$ & 0.01223 & 1.603 & .121 & Tidak signifikan \\
\hline $\mathrm{t}-2$ & -0.00232 & -.290 & .774 & Tidak signifikan \\
\hline $\mathrm{t}-1$ & 0.01599 & 2.311 & .029 & Signifikan pada level 5\% \\
\hline $\mathrm{t} 0$ & 0.00609 & .900 & .377 & Tidak signifikan \\
\hline $\mathrm{t}+1$ & 0.01132 & 2.001 & .056 & Tidak signifikan \\
\hline $\mathrm{t}+2$ & 0.01108 & 1.990 & .058 & Tidak signifikan \\
\hline $\mathrm{t}+3$ & -0.00271 & -.423 & .676 & Tidak signifikan \\
\hline $\mathrm{t}+4$ & 0.01473 & 2.118 & .044 & Signifikan pada level 5\% \\
\hline $\mathrm{t}+5$ & -0.00181 & -.252 & .803 & Tidak signifikan \\
\hline $\mathrm{t}+6$ & 0.01102 & 1.493 & .148 & Tidak signifikan \\
\hline $\mathrm{t}+7$ & 0.00262 & .281 & .781 & Tidak signifikan \\
\hline $\mathrm{t}+8$ & 0.01363 & 2.246 & .034 & Signifikan pada level 5\% \\
\hline $\mathrm{t}+9$ & 0.00363 & .497 & .624 & Tidak signifikan \\
\hline $\mathrm{t}+10$ & 0.00477 & .631 & .534 & Tidak signifikan \\
\hline $\mathrm{t}+11$ & 0.00522 & .659 & .516 & Tidak signifikan \\
\hline $\mathrm{t}+12$ & 0.00802 & 1.074 & .293 & Tidak signifikan \\
\hline $\mathrm{t}+13$ & 0.01118 & 1.649 & .112 & Tidak signifikan \\
\hline $\mathrm{t}+14$ & -0.00099 & -.151 & .881 & Tidak signifikan \\
\hline $\mathrm{t}+15$ & 0.00609 & .905 & .374 & Tidak signifikan \\
\hline $\mathrm{S}+\mathrm{s}$ & & & &
\end{tabular}

Sumber : Diolah Peneliti

Berdasarkan hasil pengujian pada tabel 4 diatas menunjukkan bahwa terdapat abnormal return yang signifikan pada hari ketujuh dan kesatu sebelum event date (t-7 \& t-1) t-7 dengan nilai t-hitung sebesar 3.159 dan t-1 nilai thitung sebesar 2.386 nilai signifikansi sebesar 0,004 dan 0.029. hari keempat dan kedelapan setelah event date $(\mathrm{t}+4 \& \mathrm{t}+8) \mathrm{t}+4$ dengan nilai thitung sebesar 2.118, $\mathrm{t}+8$ dengan nilai thitung sebesar 2.246 dan nilai signifikansi sebesar 0,044 dan 0.034 .

\section{Pembahasan Hipotesis Pengujian}

Berdasarkan hasil pengujian kandungan informasi pengumuman dividen pada tabel 4, pasar menunjukkan reaksi yang cepat karena abnormal return yang signifikan terjadi pada hari ketujuh dan pertama sebelum event date yaitu t-7 \& t-1. Ini menunjukan adanya reaksi pasar dari kebocoran informasi yang sudah diterima investor bahwa adanya pengumuman dividen. Pada hari keempat dan delapan sesudah event date $(\mathrm{t}+4 \& \mathrm{t}+8)$ terdapat reaksi pasar yang lambat dan kemudian pasar membentuk keseimbangan yang artinya reaksi pasar tidak berkepanjangan. Hal tersebut memperlihatkan bahwa Bursa Efek Indonesia sudah efisien bentuk setengah kuat secara keputusan.

Adanya abnormal return yang signifikan pada hari ketujuh dan kesatu sebelum event date $(\mathrm{t}-7$ \& $\mathrm{t}-1)$ dan hari keempat dan kedelapan setelah event date $(\mathrm{t}+4 \& \mathrm{t}+8)$ menunjukkan bahwa investor bereaksi terhadap pengumuman dividen yang dilakukan oleh perusahaan jauh hari sebelum dan setelah cum-dividend date. Reaksi ini membuktikan bahwa investor benar-benar ingin mendapatkan keuntungan yang lebih pada $\mathrm{t}+8$ setelah cum dividend date. Tetapi reaksi pasar tidak berkepanjangan sehingga investor tidak dapat memanfaatkannya untuk mendapatkan keuntungan.Hasil pengujian ini mendukung hipotesis alternatif pertama (Ho1) dalam penelitian ini, yaitu terdapat abnormal return yang signifikan di sekitar cum dividend date inisiasi dividen.

Perusahaan manufaktur di Bursa Efek Indonesia sudah efisien dalam bentuk setengah kuat dikarenakan dari 30 hari pengujian abnormal return, terdapat 26 hari yang tidak memiliki abnormal return dan 4 hari terdapat abnormal return, ini mendukung hipotesis kedua (Ho2). 


\section{Perbandingan Hasil Penelitian dengan Teori}

Dari hasil penelitian terdapat 4 abnormal return dan meskipun reaksi pasar lambat setelah pengumuman $(\mathrm{t}+4$ dan $\mathrm{t}+8)$ namun reaksi pasar cepat membentuk harga yang baru dan tidak menyebabkan abnormal return yang berkepanjangan, di buktikan dengan 31 hari penelitian terdapat 26 hari tidak terjadi abnormal return dan 4 hari terjadi abnormal return. Konsep pasar efisian menyiratkan adanya satu proses penyesuainan harga keseimbangan yang baru sebagai respon atas infomasi baru yang masuk kepasar (Tandelin 2010:219) Dapat di simpulkan hasil penelitian ini sesuai dengan teori yang ada.

\section{Perbandingan Hasil Penelitian dengan Peneliti Sebelumnya}

Peneliti sebelumnya I Gusti Ngurah Angung Putra Dwipayana Dkk 2016, dengan Judul "Pengujian Efisiensi Pasar di Bursa Efek Indonesia ( deviden)" Terdapat Abnormal Return yang berarti Pasar tidak efisien. Sama dengan peneliti Novita Sari 2015 dengan judul "Pengujian Efisiensi Pasar Semi Strong terhadap inisiasi deviden pada perusahaan yang terdaftar di BEI", terdapat pula abnormal return yang berarti pasar tidak efisien dalam bentuk setengah kuat.

Berbeda dengan penelitian Vivi Ariyani 2016 dengan judul "Pengujian Efisiensi Pasar Setengah Kuat Terhadap Pengumuman Paket Kebijakan Ekonomi VII Pada Saham Index LQ-45" dan Ketut Setya Pramana, Dkk 2016, dengan judul "Reaksi Pasar terhadap pengumuman devide di Bursa Efek Indonesia" dalam penelitian ini pasar sudah Efisien Setengah Kuat. Penelitian ini memperkuat peneliti terdahulu Vivi Ariayani 2016 dan Ketut Setya Pratama Dkk 2016 yang mengatakan Bursa Efek Indonesia sudah efisien dalam bentuk setengah kuat.

\section{PENUTUP}

Berdasarkan hasil penelitian Efisiensi Pasar Modal Setengah Kuat dapat disimpulkan bahwa,Pada Pasar Modal Setengah Kuat Pristiwa pengumuman deviden pada perusahaan Manufaktur memiliki kandungan informasi yang di tunjukan dengan adanya abnormal return yang signifikan pada hari ketujuh dan kesatu (t-7 \& $\mathrm{t}-1$ ) sebelum event date yang mengindikasikan adanya kebocoran informasi tentang akan adanya pengumuman dividen, tetapi setelah event date informasi sedikit lambat diserap yaitu pada hari keempat $(\mathrm{t}+4)$ informasi baru diserap investor dengan baik.

Pada hari kedelapan $(\mathrm{t}+8)$ investor berusaha memanfaatkan keuntungan namun pasar dengan cepat melakukan keseimbangan sehingga tidak dapat dimanfaatkan investor untuk mengambil keuntungan. Hal ini menunjukan Pasar Modal Setengah Kuat pada Perusahaan Manufaktur di Bursa Efek Indonesia sudah efisien pada periode sekitar pengumuman dividen.

Bagi para investor. Informasi yang diperoleh di pasar modal Indonesia harus secara tepat menganalisis informasi-informasi yang relevan untuk dijadikan pertimbangan dalam pengambilan keputusan, dan diharapkan investor hati-hati dan lebih bersikap rasional dalam pengambilan keputusan Investasi di Pasar Modal..

\section{DAFTAR PUSTAKA}

Amah, N \& Nuraina E. 2012. Reaksi Pasar Sebagai Dampak Publikasi Empiris pada Perusahaan Manufaktur yang terdaftar di Bursa

Dividen

Studi tahun 2004- 2006. Prestasi. 10 (2): 105-116.

Dwipayana, I Gusti Ngurah Agung Putra. 2016 Pengujian Efisiensi Pasar di Bursa Efek Indonesia. E-Jurnal Manajemen Unud Vol. 6. No.4, 2017 : $\quad 2105$ - 2132.

Gumanti, Tatang Ary. 2013. Kebijakan Dividen Teori, Empiris, dan Implikasi. Jakarta: UPP STIM YKPN

Hartono, Bambang. 2013. Sistem Informasi Manajemen Berbasis Komputer. Jakarta: Rineka Cipta. 
Hidayati, Alvin Mulya. 2014. Analisis Harga Saham dan Rata-Rata Abnormal Return Sebelum dan Sesudah Ex-Dividen Date (studi pada Emiten Indeks $\quad$ Kompas-100). Trikonomika 13 (1), h: 101-107.

Jogiyanto. 2015. Teori Portofolio dan Analisis Investasi Edisi Kesepuluh.Yogyakarta: BPFE.

Khoiruddin, Moh dan Falzati, Evy Rochfa. 2014. Reaksi pasar terhadap Dividen Announcements Perusahaan yang Sahamnya Masuk Daftar Efek Syariah. Jurnal Dinamika Manajemen 5 (2), h: 209-219.

Laopodis, Nikiforos K. 2013. Understanding Invesments: Theories and strategies. New York: Routledge.

Mafruka, Meida Faizatul. 2017. Analisis Harga Saham Sebelum Dan Sesudah Pembagin Deviden Pada Perusahaan LQ 45 Yang Terdaftar Di BEI Tahun 2012-2016. SimkiEconomic Vol. 01 No. 07 Tahun 2017 ISSN : BBBB- BBBB.

Novianti, Mega. 2013. Changes of Return of Shares Before and After Ex- Dividen Date: Case Study in Indonesia. Review Business \& Economics Research 2 (1). Pp: 511-520.

Pengumuman Pembagian Dividen yang diunduh melalui http://www.idx.co.id http://yahoo.finance.co.id pada tanggal 07 Oktober 2018

Sugiyono, 2010. Metode Penelitian Bisnis. Bandung: Alfabet.

Sukamulja Sukmawati,2017."Pengantar Pemodelan Keuangan dan Analisis Pasar Modal", Yogyakarta:Penerbit ANDI.

Suad Husnan, 2016. Teori Portofolio dan Analisis Sekurita. Edisi Keempat. Yogyakarta. UPP STIM YKPN.

Samsul, Mohamad. 2010. Pasar Modal dan Manajemen Portofolio. Jakarta. $\quad$ Erlangga.

Siaputra, Lani dan Adwin Surja Atmadja. 2006. Pengaruh Pengumuman Dividen Terhadap Perubahan Harga Saham Sebelum dan Sesudah Ex- Dividend Date di Bursa Efek Jakarta. Jurnal Akuntansi dan Keuangan, 8 (1): 71-77.

Tandelilin, Eduardus. 2010. Portfolio dan Investasi: Teori dan Aplikasi. Yogyakarta: Kanisius.

Yulia, I Gusti Ayu Artisca dan Artini, Luh Gede Sri. 2015 Dampak Pengumuman Dividen terhadap Abnormal Return pada Perusahaan LQ 45 yang Terdaftar di Bursa Efek Indeonesia. E-Jurnal Manajemen Unud 4 (12), h: 4449-4476. 